\title{
PENGARUH ALKOHOL TERHADAP PENURUNAN BERAT CEREBELLUM PADA TIKUS WISTAR REMAJA
}

\author{
Suryanti
}

\begin{abstract}
Background. Alcohol is a depressant substances that damage the body's organs. One of the organs that are vulnerable to alcohol consumption, namely the cerebellum . Consumption of alcohol will damage the cerebellum and lower density of Purkinje cells thereby reducing the weight of the cerebellum. Alcohol also mehambat activity of insulin- like growth factor receptor (IGF) I, which are growth factors and cell proliferation.

Methods. The purpose of this study was to determine the effect of alcohol on weight loss cerebellum. This type of research is the study of pure experimentation with the design of post-test only control group design to determine the weight of the cerebellum .

Result and Conclusion. Results of this study are in the group of rats that were given alcohol weight loss than the control group. Analysis cerebellum weight between groups with multiple comparasion showed that there were significant differences $(p<0.05)$ between group $B$ and group $A$.
\end{abstract}

Keyword : Cerebellum, Alkohol

\section{PENDAHULUAN}

Di negara Barat lebih dari $75 \%$ pria dan $50 \%$ wanita mengkonsumsi etanol. Sebagian besar mereka berusia muda hingga dewasa dengan frekuensi tertinggi berumur 16 - 25 tahun (Dyatmiko, 1998). Sejumlah $\quad 40,1 \%$ penduduk Indonesia berusia 18 tahun ke atas pernah minum etanol (WHO, 2004).

Etanol menyebabkan kerusakan sistem saraf baik pusat maupun perifer. Etanol juga merupakan zat depresan sistem saraf pusat yang dapat menurunkan aktivitas neuron, sehingga akan mengganggu hantaran impuls saraf. Bagian otak yang rentan terhadap kerusakan akibat konsumsi etanol secara kronik adalah cerebellum, hypothalamus, amygdala, thalamus dan cortex cerebri (Berman et al., 1997; Karhune et al., 1994).

Alkohol merupakan zat depresan sistem saraf pusat yang dapat menurunkan aktivitas neuron, sehingga akan mengganggu hantaran impuls saraf. Bagian otak yang rentan terhadap kerusakan akibat konsumsi alkohol secara kronik adalah cerebellum, hypothalamus, amygdala, thalamus dan cortex cerebri (Berman et al., 1997; Karhune et al., 1994).

Konsumsi etanol mempengaruhi struktur cerebellum. Kerusakan pada cerebellum akibat etanol berupa penurunan jumlah sel - sel Purkinje, penurunan volume lapisan molekuler dan lapisan granuler, gliosis lapisan sel granular, dan penyusutan maupun atrofi dari sel Purkinje. Konsumsi alkohol moderat secara kronik dapat menyebabkan kerusakan cerebellum dan kehilangan sel Purkinje (kepadatan sel Purkinje menurun), yang menyebabkan penurunan berat otak dan cerebellum. Sel Purkinje bersifat sensitif terhadap peningkatan kadar alkohol dalam darah baik secara akut maupun kronik (Karhune et al., 
1994; Sullivan dan Rosenbloom, 1995; Pentney dan Dlugos, 2000; Ropper dan Bron, 2005).

Alkohol juga mempengaruhi aktivitas faktor pertumbuhan yang meregulasi proliferasi dan kelangsungan hidup sel sistem saraf. Faktor-faktor yang diperlukan untuk pembelahan sel sistem saraf antara lain insulin like growth factor (IGF) I dan II. Kedua faktor ini mengikat molekul protein yang disebut reseptor IGF-I. Alkohol menghambat aktivitas sinyal fungsi reseptor IGF-I. Hal ini akan menyebabkan pembelahan sel tidak terjadi dan meningkatkan apoptosis (Goodlett et al., 2005).

Tujuan penelitian ini untuk mengetahui pengaruh alkohol terhadap berat cerebellum.

\section{METODE PENELITIAN}

Penelitian ini menggunakan metode penelitian eksperimen murni dengan rancangan post test only control group design untuk mengetahui berat cerebellum. Penelitian ini menggunakan subyek tikus wistar jantan remaja yang diberi alkohol selama dua minggu. Tikus setelah diberi perlakuan tikus diperfusi untuk diambil sampel dari jaringan cerebellum untuk ditimbang beratnya.

\section{HASIL PENELITIAN}

Hasil penelitian berat cerebellum yang penulis kumpulkan terlihat pada Tabel 1.

Tabel 1

Berat Badan Cerebellum Tikus Antar Kelompok.

\begin{tabular}{|c|c|c|c|}
\hline & \multicolumn{2}{|c|}{ Kelompok* } & \multirow{2}{*}{$\begin{array}{c}\mathrm{p} \\
\text { value- }\end{array}$} \\
\hline & $A$ & $\mathrm{~B}$ & \\
\hline Jumlah tikus & 8 & 8 & \\
\hline $\begin{array}{c}\text { Berat bdn sblm } \\
\text { perlakuan (gr) }\end{array}$ & $\begin{array}{c}50 \\
\pm 3,8\end{array}$ & $\begin{array}{c}57 \\
\pm 7,1\end{array}$ & 0,000 \\
\hline $\begin{array}{l}\text { Berat bdn ssdh } \\
\text { perlakuan (gr) }\end{array}$ & $\begin{array}{l}48,1 \\
\pm 3,7\end{array}$ & $\begin{array}{l}46,9 \\
\pm 5,9\end{array}$ & 0,000 \\
\hline $\begin{array}{c}\text { Berat } \\
\text { cerebellum (gr) }\end{array}$ & $\begin{array}{l}231,9 \\
\pm 12,4\end{array}$ & $\begin{array}{l}219,3 \\
\pm 12,1\end{array}$ & 0,047 \\
\hline
\end{tabular}

Keterangan:

* Kelompok A: $\mathrm{NaCl}$ 0,9\% (ip) + air (oral)

Kelompok B: alkohol (ip) + air (oral)

$\dagger P$ value diuji dengan menggunakan one way anova.

Hasil ditampilkan dengan rata-rata dan standard deviasi.

Analisa berat cerebellum antar kelompok dengan multiple comparasion menunjukkan bahwa ada perbedaan bermakna $(p<0,05)$ antara kelompok $B$ dengan kelompok A. Kesimpulannya bahwa alkohol menurunkan berat cerebellum.

\section{PEMBAHASAN}

Alkohol menurunkan jumlah sel Purkinje sehingga menurunkan berat cerebellum. Alkohol menyebabkan penurunan jumlah sel Purkinje cerebellum pada manusia (Karhune et al., 1994). Alkohol larut dalam membran lipid, sehingga meningkatkan fluiditas membran sel yang mempengaruhi reseptor GABAergik pada neuron Purkinje, menghambat transmisi impuls sel saraf, menekan aktivitas jalur saraf eksitatorik dan meningkatkan saraf inhibitorik (Trujilo dan Chin, 1996).

Ada beberapa mekanisme yang diduga mendasari kerusakan cerebellum akibat alkohol. Pertama adalah kerusakan cerebellum akibat alkohol melalui pengaruhnya terhadap faktor pertumbuhan yang meregulasi proliferasi dan kelangsungan hidup sel. Faktor pertumbuhan yang dibutuhkan untuk pembelahan sel yang normal antara lain adalah insulin-like growth factor (IGF) I dan II. Kedua faktor tersebut berikatan dengan reseptor IGF-I pada permukaan sel. Alkohol mempengaruhi reseptor ini. Maka meskipun IGF-I dan II berikatan dengan reseptor, tapi apabila sinyal 
dari reseptor terblok, sel tidak akan bisa membelah. Alkohol juga menginduksi kematian sel dengan menginhibisi faktor pertumbuhan sel yang sudah berfungsi dan sudah tidak membelah. IGF-I dan reseptornya juga berfungsi menjaga kelangsungan hidup sel yang tidak membelah dan menjaga apoptosis.

Sehingga ketika reseptornya diintervensi alkohol, proses ini terganggu, sehingga kelangsungan hidup sel terganggu (Goodlett dan Horn, 2001).

Mekanisme kedua perusakan cerebellum melalui toksisitasnya pada neuron. Proses metabolisme alkohol adalah sebagai berikut: alkohol diubah menjadi asetaldehid oleh enzim alkohol dehidrogenase. Asetaldehid sepuluh kali lebih toksik dibandingkan dengan alkohol. Akumulasi asetaldehid akan menurunkan antioksidan dan meningkatkan ROS sehingga dapat memicu kematian (apoptosis) sel Purkinje (Rintala, et al,. 2000). Zima, (2001) mengungkapkan adanya akumulasi asetaldehid di otak tikus di daerah hemisfer otak, striatum, batang otak, hipotalamus, dan cerebellum.

Metabolisme alkohol dengan jalur P450 menggunakan NADPH. NADPH berfungsi dalam jalur glutathione peroksidase sebagai pereduksi glutathione teroksidase (GSSG), menjadi glutathione tereduksi (GSH). Proses ini merupakan jalur yang dapat menurunkan ROS (Goodlett et al., 2005). Alkohol selain meningkatkan produksi radikal bebas juga menurunkan kadar antioksidan. Maka perlu suplemen antioksidan yang dapat mencegah kerusakankerusakan akibat alkohol. Penelitian Goodlett (2005) menunjukkan bahwa suplemen vitamin E dapat menurunkan apoptosis akibat alkohol pada hippocampus, dan sel Purkinje pada cerebellum.
Alkohol larut dalam membran lipid. Sehingga alkohol dapat meningkatkan fluiditas membran sel yang mempengaruhi reseptor GABAergik pada neuron Purkinje, menghambat transmisi impuls sel saraf, menekan aktivitas jalur saraf eksitatorik dan meningkatkan saraf inhibitorik. Alkohol menyebabkan penurunan jumlah sel Purkinje. Sel Purkinje terlibat dalam fungsinya sebagai pengaturan gerakan dan pembelajaran koordinasi motorik. Sehingga apabila jumlah sel Purkinje mengalami penurunan, maka penjalaran impuls dan proses pembelajaran motorik terganggu (Trujilo dan Chin, 1996; Karhune et al., 1994).

Hasil penelitian ini menunjukkan bahwa berat cerebellum pada kelompok yang diberi alkohol lebih kecil dibanding kelompok yang diberi nacl $0,9 \%$. Hal ini disebabkan karena Alkohol menyebabkan terjadinya degenerasi dan regresi dendrit neuron Purkinje. Hal ini menyebabkan kerusakan sel Purkinje sehingga jumlahnya menurun sehingga beratnya akan turun.

Alkohol juga mempengaruhi faktor pertumbuhan yang meregulasi proliferasi sel sistem saraf. Faktorfaktor tersebut yaitu insulin like growth (IGF) I dan II. Alkohol menghambat aktivitas sinyal fungsi reseptor IGF-I yang meningkatkan apoptosis (Goodlett et al., 2005). Metabolisme alkohol di otak meningkatkan produksi ROS dan RNS dan menurunkan kadar antioksidan sehingga ROS dan RNS lebih banyak daripada antioksidan. Keadaan ini membuat sel rentan terhadap stres oksidatif dan menyebabkkan kematian sel Purkinje sehingga berat cerebellum juga akan berkurang (Goodlett et al., 2005; Deitrich et al., 2006).

Berat cerebellum saat selesai perfusi menunjukkan bahwa rerata berat cerebellum paling ringan adalah 
kelompok alkohol dan kelompok yang diberi $\mathrm{Nacl} 0.9 \%$ lebih berat. Hal ini terjadi karena kelompok alkohol banyak mengalami kerusakan sel dan kematian sel. Sehingga kepadatan sel atau volumenya terganggu. Keadaan tersebut juga menyebabkan terjadi penurunan jumlah sel Purkinje dan berat cerebellum.

\section{KESIMPULAN}

Dari hasil penelitian ini dapat diambil kesimpulan bahwa: Alkohol menyebabkan penurunan berat cerebellum.

\section{SARAN}

Alkohol menyebabkan penurunan berat cerebellum, maka untuk penelitian lebih lanjut supaya melakukan penelitian lanjutan tentang apa yang mencegah atau menghambat zat adaptif seperti alkohol masuk dalam siklus metabolisme khususnya dalam otak baik cerebellum atau hipokampus. Sehingga berat cerebellum dan fungsinya tidak terganggu, mengingat begitu besar pentingnya fungsi otak untuk kehidupan seharihari.

\section{DAFTAR PUSTAKA}

Berman, M. O., Shagri, B., Evert D. I., and Epstein, C. 1997. "Impairments of Brain and Behavior: The Neurological Effects of Alcohol". Alcohol Health and Research World.

Deitrich, R., Zimatkin, S., and Pronko, S. 2006. "Oxidation of Ethanol in the Brain and Its Consequences". Journal of Alcohol Research and Health.
Dyatmiko. 1998. Alkoholisme, Epidemi Baru yang Meresahkan. Medika

Goodlett, C. R., Horn, K. H., and Zhou, F. C. 2005. "Alcohol Teratogenesis: Mechanisms of Damage and Strategies for Intervention". Society for Experimental Biology and Medicine.

-2001. "Mechanisms of Alcohol-Induced Damage to theDeveloping Nervous Syste". Alcohol Research and Health.

Karhune, P. J., Erkinjuntiti T., and Laipala P. 1994. "Moderate Alcohol Comsumsion and Loss of Cerebellar Purkinje Cell". British Medical Journal.

Pentney, C. A., and Dlugos, R. J. 2000. "Cerebellar Purkinje Neuron With Altered Terminal Dendritic Segment are Present in all Lobule of The Cerebellar Vermis of Ageing EthanolTreated F334 Rats". Alcohol and Alcoholism.

Rintala, J., Jaatinen, P., Parkkila, S., Sarviharju, M., Kiianmaa, K., Hervonen, A., and Niemela, $\mathrm{O}$. $2000 . \quad$ 'Evidence of Acetaldehide-Protein Adduct Formation in Rat Brain After Lifelong Consumption of Ethanol". Alcohol and Alcoholism.

Ropper, A. H., and Bron, R. H. 2005. Adam and Victor's Principles of Neurology, $8^{\text {th }}$ ed. Mc Graw Hill, USA.

Sullivan, E.V., et al. 2000. "Contribution of Alcohol Abuse to Cerebellar Volume Deficits in Men With Schizophrenia". Psychiatric Research Institute. 
Trujillo, K. A., and Chinn, A. B. 1996. "Ethanol" $U R L:$ http://www.csusm.edu/DandB/ Ethanol.html. Diakses pada tanggal 1 Maret 2008.

WHO. 2004. 'WHO Global Status Report on Alcohol 2004, Country Profiles South-East Asia Readion". URL:http//www.who.int/substa nce.abme/publications/en/indo nesia.pdf. Diakses pada tanggal 20 Mei 2009.
Zima, T., et al. 2001. "Oxidative Stress, Metabolism of Ethanol and Alcohol-Related Diseases". Journal of Biomedical Science.

* Dosen Politeknik Kemenkes RI Surakarta Jawa tengah 